REFLEKSI HUKUM

Jurnal Ilmu Hukum
p-ISSN 2541-4984 | e-ISSN 2541-5417

Volume 2 Nomor 2, April 2018, Halaman 125 - 138

DOI: https://doi.org/10.24246/jrh.2018.v2.i2.p125-138

Open access at: http:// ejournal.uksw.edu/refleksihukum

Penerbit: Fakultas Hukum Universitas Kristen Satya Wacana

\title{
JAMINAN KEPASTIAN KEPEMILIKAN BAGI PEMEGANG HAK ATAS TANAH DALAM PENDAFTARAN TANAH MENURUT UUPA
}

\author{
Christiana Tri Budhayati \\ Fakultas Hukum Universitas Kristen Satya Wacana \\ Korespondensi: tri.budhayati@staff.uksw.edu
}

\begin{abstract}
Abstrak
Tulisan ini hendak membahas tentang jaminan kepastian hukum bagi pemegang hak atas tanah yang namanya telah tertera dalam sertifikat. Tujuan dari pendaftaran tanah adalah untuk memberikan kepastian hukum dan perlindungan hukum bagi pemilik hak atas tanah baik kepastian mengenai subyek, obyek maupun hukumnya. Pasal 32 ayat (2) PP Nomor 24 Tahun 1997 telah memberikan jaminan kepastian tersebut kepada pemegang hak atas tanah, yakni dengan adanya lembaga Rechtsverwerking. Bahwa terhadap pemegang hak atas tanah yang sertifikatnya telah diterbitkan 5 (lima) tahun atau lebih, tidak dapat diganggu gugat lagi oleh pihak lain yang merasa memilikinya. Pada faktanya ada beberapa gugatan melalui Pengadilan Tata Usaha Negara dalam putusannya menyatakan sertifikat batal atau tidak sah, sekalipun usia sertifikat sudah lebih dari 5 (lima) tahun, karena bertentangan dengan undang undang atau salah dalam prosedur penerbitannya. Putusan tersebut tentu akan memberikan rasa "waswas" kepada pihak yang namanya tercantum dalam sertifikat karena setiap saat dapat dilakukan pembatalan sertifikat.
\end{abstract}

Kata kunci: $\begin{aligned} & \text { Pembatalan Sertifikat, Kepastian Hukum Pemegang Sertifikat, } \\ & \text { Rechtsverwerking }\end{aligned}$

\begin{abstract}
This article will analyze the guarantee of legal certainty for rights holder of land, whose certificate on behalf of his/her name. The purpose of land registration is to maintain the legal certainty and to give the person a legal protection. Article 32 (2) PP No. 24 of 1997 has provided the guarantee of legal certainty to rights holder of land by establishing rechtsverwerking institution. It means the rights holder of land whose certificate is issued for 5 (five) years or more, shall not be sued by others. In fact, there have been lawsuits in administrative courts that voided the validity of the certificates which were issued for more than 5 (five) years, using the reason that they were not accordance with laws substantially or procedurally. Those decisions have created the uncertainty for persons whose the names were listed in the certificates.
\end{abstract}

Keywords: Certificate nullification, legal certainty of certificate owner, rechtsverwerking 


\section{PENDAHULUAN}

\section{Salah satu pertimbangan}

Pemerintah Indonesia mengganti hukum agraria kolonial (hukum agraria jaman Hindia Belanda) dengan hukum agraria nasional yang kemudian dituangkan dalam Undang Undang Nomor 5 Tahun 1960 tentang Peraturan Dasar Pokok Pokok Agraria (selanjutnya disebut UUPA) adalah adanya ketidak pastian hukum bagi pemegang hak atas tanah khususnya untuk hak-hak adat. Hal ini terjadi karena hak adat tidak didaftarkan secara Rechts Cadaster seperti halnya hak barat, akan tetapi dilakukan pendaftaran tanah secara Fiscaal Cadaster. Pendaftaran tanah secara Rechts Cadaster akan memberikan kepastian hukum baik terhadap subyek, obyek maupun hukumnya, dengan product/keluaran dari pendaftaran tanah secara Rechts Cadaster adalah sertifikat sebagai alat bukti pemilikan hak atas tanah. Sedangkan untuk hak adat dilakukan pendaftaran tanah secara Fiscaal Cadaster, yakni pendaftaran tanah yang bertujuan untuk menentukan besarnya pajak yang harus dibayar, product/keluaran dari pendaftaran tanah secara Fiscaal Cadaster adalah bukti pembayaran pajak, yang bukan merupakan bukti pemilikan hak atas tanah. Pendaftaran tanah secara Fiscaal Cadaster akan memberikan dampak persengketaan tanah mengenai luas, batas, dan pemilikan hak atas tanah tidak dapat dihindari. ${ }^{1}$

Mempertimbangkan kenyataan tersebut, untuk menjamin kepastian hukum bagi pemegang hak atas tanah, UUPA mengamanatkan pada pemerintah untuk melakukan pendaftaran tanah sebagaimana dituangkan dalam Pasal 19 UUPA, kemudian ditindaklanjuti dengan diundangkannya Peraturan Pemerintah Nomor 10 Tahun 1961 tentang Pendaftaran Tanah (selanjutnya disebut PP Nomor 10 Tahun 1961) yang menjadi dasar pelaksanaan pendaftaran tanah di Indonesia. Walaupun telah diundangkan PP Nomor 10 Tahun 1961 tersebut, nampaknya belum memenuhi harapan Pemerintah, oleh karena itu pada tanggal 8 Juli 1997 ditetapkan Peraturan Pemerintah Nomor 24 Tahun 1997 tentang Pendaftaran Tanah ( selanjutnya disebut PP Nomor 24 Tahun 1977). Sebagaimana dalam Penjelasan Umum PP Nomor 24 Tahun 1997, dikemukakan bahwa untuk memberikan kepastian hukum dibidang pertanahan perlu untuk mengadakan penyempurnaan ketentuan yang mengatur pendaftaran tanah. ${ }^{2}$ Maknanya adalah bahwa PP Nomor 10 Tahun 1961 belum memberikan jaminan kepastian hukum kepada pemegang hak atas tanah.

Salah satu hal baru yang ada dalam PP Nomor 24 Tahun 1997 adalah diaturnya lembaga Rechtsverwerking, yang tidak dikenal dalam PP No 10 Tahun 1961. Jika dalam PP Nomor 10 Tahun 1961, sepanjang waktu pemegang hak atas tanah yang telah mempunyai sertifikat dapat digugat atas kepemilikan tanahnya, akan tetapi dalam PP Nomor 24 Tahun 1997, gugatan demikian ada batas waktunya

\footnotetext{
1 Christiana Tri Budhayati, Hak Atas Tanah, Peralihan Dan Pendaftaran ( FH UKSW 2017) 111.
}

2 Penjelasan Umum Peraturan Pemerintah Nomor 10 Tahun 1997 tentang Pendaftaran Tanah. 
yakni maksimal 5 (lima) tahun sejak diterbitkanya sertifikat. Hal ini nampak dalam Pasal 32 ayat (2) PP Nomor 24 Tahun 1997 yang menyatakan:

Dalam hal atas suatu bidang tanah sudah diterbitkan sertifikat secara sah atas nama orang atau badan hukum yang memperoleh tanah tersebut dengan itikad baik dan secara nyata menguasainya, maka pihak lain yang merasa mempunyai hak atas tanah itu tidak dapat lagi menuntut pelaksanaan hak tersebut apabila dalam waktu 5 (lima) tahun sejak diterbitkannya sertifikat itu telah tidak mengajukan keberatan secara tertulis kepada pemegang sertifikat dan Kepala Kantor Pertanahan yang bersangkutan ataupun tidak mengajukan gugatan ke Pengadilan mengenai penguasaan tanah atau penerbitan sertifikat tersebut.

Dari Pasal 32 ayat (2) PP Nomor 24 Tahun 1997 tersebut, dapat ditarik pemahaman bahwa pihak lain yang merasa berhak dan keberatan atas diterbitkannya sertifikat tersebut mempunyai hak untuk melakukan gugatan guna pembatalan sertikat dalam rentangan waktu 5 (lima) tahun saja. Artinya bahwa hak menuntut akan hilang jika dalam rentang waktu lima tahun tidak dimanfaatkan.

Namun dalam faktanya ada beberapa putusan Pengadilan Tata Usaha Negara (selanjutnya disebut PTUN) yang telah membatalkan sertifikat yang berusia lebih dari 5 (lima) tahun. Ini menunjukkan bahwa apa yang diinginkan oleh Pasal 3 huruf a PP Nomor 24 Tahun 1997 yang menyatakan bahwa tujuan pendaftaran tanah adalah untuk memberikan kepastian hukum dan perlindungan hukum kepada pemegang hak atas tanah dapat saja tidak terwujud. Tulisan ini hendak membahas tentang hal tersebut, apakah ada landasan yuridis pembatalan sertifikat yang berusia lebih dari lima tahun sah secara hukum, sehingga kepastian hukum dan perlindungan hukum pada pemegang sertifikat menjadi tidak terjamin.

\section{PEMBAHASAN}

Pada bagian ini akan dipaparkan secara berturut-turut tentang sistem pendaftaran tanah menurut UUPA, lembaga Rechtsverwerking sebagai sarana pemberian kepastian hukum dan perlindungan hukum kepada pemegang hak atas tanah yang telah 5 (lima) tahun atau lebih namanya tercantum dalam sertifikat serta substansi tentang ketidak absahan putusan pejabat tata usaha Negara (Kantor Pertanahan) sebagai dasar pembatalan sertifikat. Dengan demikian akan nampak bahwa pembatalan sertifikat yang dilakukan melalui gugatan berdasarkan ketidak absahan putusan pejabat tata usaha Negara (dalam hal ini Kantor Pertanahan) dalam penerbitan sertifikat melalui PTUN, akan mengakibatkan adanya ketidak pastian hukum bagi pemegang hak atas tanah, yang telah mempunyai sertifikat yang berusia 5 (lima) tahun atau lebih.

\section{Sistem Pendaftaran Tanah Menurut UUPA.}

Sebagaimana telah dikemukakan diatas, Pendaftaran tanah yang tertuang dalam Pasal 19 UUPA ditujukan untuk menjamin kepastian hukum dan perlindungan hukum kepada pemegang hak atas tanah telah ditindak lanjuti dengan diundangkannya peraturan pelaksana yakni PP No 10 Tahun 1960 
yang telah dicabut dengan PP Nomor 24 Tahun 1997. Sebagai peraturan pelaksana PP 24 Tahun 1997 tersebut adalah Peraturan Menteri Agraria/Kepala Badan Pertanahan Nasional Nomor 3 Tahun 1997.

Pendaftaran tanah sebagaimana dirumuskan pada Pasal 1 angka 1 PP Nomor 24 Tahun 1997 merupakan kegiatan yang dilakukan oleh Pemerintah secara terus menerus, berkesinambungan, tidak hanya pada saat pertama kali pendaftaran tanah akan tetapi secara terus menerus sepanjang ada perubahan baik obyek maupun subyeknya. Dengan demikian kegiatan pendaftaran tanah dapat dilakukan pada saat pemegang hak mengajukan permohonan pendaftaran tanah untuk yang pertama kalinya maupun kegiatan pendaftaran tanah yang merupakan kegiatan pemeliharaan karena ada perubahan terhadap obyek dan subyeknya, sebagaimana dituangkan dalam Pasal 11 PP Nomor 24 Tahun 1997. Pelaksaaan pendaftaran tanah tidak hanya kewajiban dari Pemerintah, sebagaimana dituangkan dalam Pasal 5 PP Nomor 24 Tahun 1997, akan tetapi juga merupakan kewajiban pemegang hak atas tanah sebagaimana diatur dalam Pasal 23 ayat (1); Pasal 32 ayat (1); Pasal 38 ayat (1) UUPA. Pemegang hak atas tanah mempunyai kewajiban untuk aktif melakukan pendaftaran tanah, jika ada perubahan baik fisik maupun yuridis berkaitan dengan hak atas tanah yang dimilikinya, agar dapat melindungi dirinya atas kepemilikan hak atas tanahnya.

Disamping untuk memberikan kepastian hukum dan perlindungan hukum kepada pemegang hak atas tanah, pendaftaran tanah juga dimaksudkan untuk menciptakan tertib administrasi pertanahan, sebagaimana dituangkan dalam Pasal 19 ayat (1) UUPA yo Pasal 3 PP Nomor 24 Tahun 1997. Pasal 19 ayat (2) huruf c yo Pasal 4 ayat (1) PP Nomor 24 Tahun 1997, kegiatan pendaftaran tanah meliputi pemberian sertifikat sebagai alat pembuktian yang kuat. Sertifikat merupakan alat bukti yang kuat dimaksudkan adalah bahwa apa yang dituangkan dalam sertifikat dianggap benar sepanjang tidak ada alat bukti yang membuktikan sebaliknya. Ini berarti bahwa sertifikat bukan satusatunya alat bukti pemilikan hak atas tanah menurut UUPA. Sertifikat sebagai alat bukti yang kuat merupakan ciri dari pendaftaran tanah negatif. Dalam sistem pendaftaran tanah negatif, sertifikat sebagai alat bukti yang kuat, apa yang tercantum dalam sertifikat akan dianggap benar sepanjang tidak dibuktikan sebaliknya, sehingga sertifikat bukan satu-satunya alat bukti pemilikan tanah. Petugas pendaftaran tanah akan menerima begitu saja keterangan yang diberikan oeleh pemohon. Dalam sistem pendaftaran tanah negatif ini, pemegang hak yang namanya tercantum dalam sertifikat perlu "was-was", karena setiap saat sertifikat hak atas tanahnya dapat dinyatakan tidak sah, karena didasarkan pada keterangan yang tidak benar. Dasar dari sistem ini adalah asas nemo plus yuris, yakni bahwa orang tidak dapat mengalihkan hak melebihi hak yang ada padanya. ${ }^{3}$

$3 \quad$ Ibid. 
Disamping itu, dikenal sistem pendaftaran tanah positif. Pada sistem pendaftaran tanah positif, keterangan yang tercantum dalam buku pendaftaran tanah dan dalam sertifikat adalah mutlak kebenarannya. Sertifikat sebagai alat bukti yang mutlak dalam pemilikan hak atas tanah. Konsekwensinya adalah bahwa petugas pendaftaran tanah dalam sistem positif harus aktif dalam mengumpulkan bukti kepemilikan tanah tersebut, karena untuk membuktikan pemilikan hak atas tanah hanya dapat dibuktikan dengan sertifikat saja. Kelebihan dari sistem pendaftaran tanah positif adalah adanya kepastian hukum bagi pemegang hak atas tanah, dimana tidak dapat dilakukan pembatalan sertifikat atas pemegang yang namanya tercantum dalam sertifikat. Sistem pendaftaran tanah ini mendasarkan pada asas itikad baik, orang yang mendapat hak atas tanah dengan itikad baik, akan tetap menjadi pemegang hak atas tanah yang sah menurut hukum. ${ }^{4}$

Dengan berpedoman pada karakter pendaftaran tanah tersebut diatas, pendaftaran tanah di Indonesia menganut sistem negatif. Akan tetapi bukan sistem pendaftaran negatif murni, hal ini nampak dalam Pasal 19 ayat (2) huruf c UUPA jo Pasal 17 ayat (1) PP Nomor 24 Tahun 1997, dimana dalam melakukan pendaftaran tanah petugas pendaftaran tanah (Kantor Pertanahan), akan melakukan pengukuran, petugas akan mencari informasi baik tentang subyek maupun obyek yang didaftarkan. Ini artinya bahwa petugas pendaftaran tanah bersikap aktif, tidak hanya mempercayai informasi dari para pemohon sertifikat. Budi Harsono menyebutnya sebagai sistem pendaftran tanah negatif bertendens positif. 5

Sementara itu jika dilihat dari obyek yang didaftarkan, ada dua sistem buku tanah/pendaftaran hak (registration of titles) dan sistem perbuatan hukum (registration of deeds). Dalam sistem buku tanah, hak atas tanah yang didaftarkan, sedangkan dalam sistem perbuatan hukum, maka perbuatan hukumnya yang didaftarkan. ${ }^{6}$ Dengan mengacu pada batasan tersebut diatas, menurut penulis, UUPA menganut sistem buku tanah, yakni hak atas tanahnya yang didaftarkan. Hal ini nampak dalam Pasal 23, Pasal 32 UUPA maupun dalam Pasal 9 PP Nomor 24 Tahun 1997, dinyatakan bahwa semua hak atas tanah maupun hak jaminan, pendaftrannya diwajibkan, dibukukan dalam buku tanah. Demikian juga dalam pendaftaran tanah menurut UUPA dan peraturan pelaksananya, adanya buku tanah yang memuat data yuridis maupun data fisik setiap pemegang hak atas tanah.

Dengan berpedoman pada sistem pendaftaran tanah yang dianut oleh UUPA sebagaimana dijelaskan diatas, maka setiap pemilik hak atas tanah yang sebenarnya dapat memperoleh kesempatan untuk mendapatkan tanahnya kembali sekalipun tanah 
tersebut telah didaftarkan atas nama orang lain dan telah ada sertifikatnya.

\section{Jaminan Kepastian Hukum Pemilikan Hak Atas Tanah.}

Tujuan dari pendaftaran tanah sebagaimana dituangkan dalam Pasal 19 ayat (1) UUPA yo Pasal 3 PP Nomor 24 Tahun 1997 adalah untuk memberikan kepastian hukum dan perlindungan hukum kepada pemegang hak atas tanah. Konstruksi hukum berkaitan dengan kepastian hukum disini dimaksudkan adalah kepastian hukum yang berkaitan dengan obyek, subyek dan hukumnya. Untuk memberikan jaminan kepastian hukum tentang obyeknya, diperlukan data fisik dari tanah yang dimohonkan pendaftarannya. Oleh karena itu dilakukan pengukuran, penentuan batas-batas dari tanah yang bersangkutan dan kemudian ditempatkan "pathok" disetiap sudut bidang tanah tersebut. Penentuan batas dan penempatan pathok tanah batas berdasarkan kesepakatan pihak yang berkepentingan, dalam hal ini adalah pemegang hak atas tanah yang berbatasan dengan bidang tanah yang dimohonkan sertifikatnya. Setelah ditentukan batas-batasnya, maka dilakukan pengukuran dan selanjutnya dipetakan dalam peta dasar pendaftaran tanah. ${ }^{7}$ Peta dasar ini akan menggambarkan kondisi fisik dari tanah yang dimohonkan pendaftarannya, yang meliputi bentuk, luas, batas dan letak tanah yang bersangkutan. Dengan demikian ada jaminan kepastian hukum dari sisi obyeknya. Kebutuhan peta pendaftaran tanah yang menggambarkan tentang obyek tanah yang bersangkutan sangat penting untuk menghindari ada tumpang tindih suatu lokasi bidang tanah. ${ }^{8}$ Kepastian hukum terhadap subyeknya akan sangat berpengaruh terhadap keabsahan pemilikan tanah yang bersangkutan. Kepastian subyek pemilik hak atas tanah mempunyai makna penting untuk dapat mengetahui dengan siapa seseorang akan melakukan suatu perbuatan hukum dengan obyek tanah tersebut, atau menentukan siapa yang mempunyai wewenang dan kewajiban terhadap tanah tersebut. Untuk dapat memenuhi kepastian subyek pemilik hak atas tanah yang bersangkutan, sejarah perolehan hak tersebut menjadi hal yang sangat diperlukan. Melalui bukti perolehan tanah akan sangat penting untuk menetapkan kepemilikan tanah tersebut. Oleh karena itu faktor perolehan dengan itikad baik perlu diperhatikan dalam menentukan subyek pemegang hak atas tanah.

\section{Lembaga Rechtsverwerking sebagai sarana pemberian kepastian hukum dan perlindungan hukum kepada pemegang hak atas tanah.}

Dengan adanya kelemahan sistem pendaftaran tanah yang negatif, yakni bahwa apa yang tertuang dalam sertifikat dianggap benar sampai adanya yang menyatakan sebaliknya, tidak akan memberikan kepastian hukum dan perlindungan hukum 
kepada pemegang hak atas tanah yang namanya tertulis dalam sertifikat. Setiap saat pihak yang merasa berhak dan dapat membuktikan kepemilikannya, dapat mengajukan permohonan pembatalan sertifikat tersebut.

Dalam Penjelasan Umum PP Nomor 24 Tahun 1997, dinyatakan bahwa untuk memberikan kepastian hukum kepada pemegang hak atas tanah, maka diberi penegasan sejauh mana kekuatan pembuktian sertifikat, yang dinyatakan sebagai alat pembuktian yang kuat oleh UUPA. Untuk itu diberikan ketentuan bahwa selama belum dibuktikan sebaliknya, data fisik dan data yuridis yang tercantum dalam sertifikat harus diterima sebagai data yang benar. Orang tidak dapat menuntut tanah yang sudah bersertifikat atas nama pihak lain, jika selama 5 (lima) tahun sejak dikeluarkannya sertifikat itu, tidak mengajukan gugatan ke Pengadilan, sedangkan pihak lain tersebut memperoleh dengan itikad baik dan menguasai tanah yang bersangkutan. ${ }^{9}$ Hal ini juga diatur dalam Pasal 32 PP Nomor 24 Tahun 1977 yang menyatakan:

(1) Sertifikat merupakan tanda bukti hak yang berlaku sebagai alat pembuktian yang kuat mengenai data fisik dan data yuridis yang termuat di dalamnya, sepanjang data fisik dan data yuridis tersebut sesuai dengan data yang ada dalam surat ukur dan buku tanah yang bersangkutan.

(2) Dalam hal atas suatu bidang tanah sudah diterbitkan sertifikat secara sah atas nama orang atau badan hukum yang memperoleh tanah tersebut dengan itikad baik dan secara nyata menguasainya, maka pihak lain yang merasa mempunyai hak atas tanah itu tidak dapat lagi menuntut pelaksanaan hak tersebut apabila dalam waktu 5 (lima) tahun sejak diterbitkannya sertifikat itu telah tidak mengajukan keberatan secara tertulis kepada pemegang sertifikat dan Kepala Kantor Pertanahan yang bersangkutan ataupun tidak mengajukan gugatan ke Pengadilan mengenai penguasaan tanah atau penerbitan sertifikat tersebut.

Pada penjelasan Pasal 32 ayat (2) PP Nomor 24 Tahun 1997, dinyatakan bahwa kelemahan pendaftaran tanah negatif adalah kemungkian gugatan oleh pihak yang merasa mempunyai hak atas tanah kepada pihak yang namanya telah tercantum dalam sertifikat. Karena Hukum Tanah Nasional mendasarkan pada hukum adat, maka untuk mengatasi kelemahan tersebut digunakan lembaga Rechtsverwerking, suatu lembaga pelepasan hak yang dikenal dalam hukum adat. Dalam hukum adat jika seorang selama sekian waktu tertentu membiarkan tanahnya tidak dikerjakan, kemudian tanah dikerjakan orang lain, yang memperolehnya dengan itikad baik, maka hilanglah hak-nya untuk menuntut kembali tanah tersebut, dalam hukum adat dikenal dengan Rechtsverwerking. ${ }^{10}$ Berkaitan dengan Rechtsverwerking, Kartini Mulyadi menyatakan bahwa lembaga yang dengan lampaunya waktu: ${ }^{11}$

a. Orang yang telah memegang hak atas tanahnya menjadi kehilangan haknya karena selama waktu

\footnotetext{
$9 \quad$ Lihat Penjelasan Umum PP Nomor 24 Tahun 1997.

10 Lihat Penjelasan Pasal 32 ayat (2) PP Nomor 24 tahun 1997.

11 Kartini Mulyadi dan Gunawan Widjaja , Hak-Hak Atas Tanah (Prenad Medika, 2004) 83.
} 
tertentu tidak mengusahakan hak atas tanah tersebut.

b. Orang yang dengan itikad baik telah menguasai dan memanfaatkan bidang tanah tersebut, berhak untuk memperoleh hak atas tanah yang telah dimanfaatkan olehnya tersebut.

Dengan mengacu pendapat Kartini Mulyadi tersebut diatas, ada dua hal yang penting untuk dicermati berkaitan dengan lembaga Rechtsverwerking, pertama: bahwa jika tanah tidak dikelola dengan baik, dalam waktu tertentu, pemilik akan kehilangan haknya, kedua jika seorang telah menguasai dan mengelola tanah yang telah diperolehnya dengan itikad baik, akan memperoleh tanah tersebut.

Konsep Rechtsverwerking ini dikenal dalam hukum adat sebagai konsekwensi dari adanya pola hidup nomanden dari masyarakat adat, selalu berpindah-pindah tempat tinggal dengan jalan membuka hutan dan meninggalkannya jika dirasa tidak memberikan hasil dan tidak dapat dimanfaatkannya. Dalam hukum di Indonesia, Lembaga Rechtsverwerking ini telah diakui keberadaannya dalam hukum nasional, terbukti dengan adanya beberapa putusan Mahkamah Agung yang mendasarkan putusannya pada Rechtsverwerking ini ${ }^{12}$.

Dengan mendasarkan pada Penjelasan Umum dan bunyi Pasal 32 ayat (2) PP Nomor 24 Tahun 1997 tersebut dapat disimpulkan bahwa seorang yang telah mempunyai sertifikat hak atas tanah dapat terlepas dari gugatan kepemilikan tanah jika memenuhi persyaratan yakni:

1. Tanah diperoleh dengan itikad baik.

2. Secara fisik pihak yang namanya tercantum dalam sertifikat atau orang lain dengan persetujuannya menguasai tanah tersebut.

3. Tidak ada gugatan dalam rentangan waktu 5 (lima) tahun sejak dikeluarkannya sertifikat.

Syarat tersebut diatas bersifat komulatif.

Dengan adanya persyaratan tersebut akan memberikan kepastian hukum dan perlindungan hukum kepada pemegang hak atas tanah yang namanya tercantum dalam sertifikat. Pemegang sertifikat yang memenuhi syarat sebagaimana ditentukan Pasal 32 ayat (2) PP Nomor 24 Tahun 1997 tersebut diatas, dapat merasa aman akan kepemilikan tanahnya jika telah lewat 5 (lima) tahun sejak penerbitan sertifikat. Bahwa dengan lewatnya waktu 5 (lima) tahun tersebut, pemegang sertifikat tidak dapat digugat kepemilikan tanahnya, karena pihak lain yang merasa memiliki tanah dianggap tidak menggunakan haknya untuk menggugat pihak yang namanya tertera dalam sertifikat guna mempertahankan kepemilikannya. Walaupun demikia secara norma masih dimungkinkan pemegang hak sebenarnya menggugat kepemilikan tanahnya melalui gugatan kepemilikan lewat Pengadilan Negeri, jika kepemilikan tanah oleh pihak yang namanya tertera dalam sertifikat tidak didasarkan pada itikad baik. Dengan

12 Lihat Putusan MA Nomor 210/K/Sip/1956; Putusan MA Nomor 361/K/Sip/1958;Putusan MA Nomor 229/K/Sip/1957; Putusan MA Nomor 70/K/Sip/1959 dan Putusan MA Nomor 359/K/Sip/1957. 
adanya Pasal 32 ayat (2) PP Nomor 24 Tahun 1997 tersebut, telah ada keinginan pemerintah untuk tetap melindungi setiap pemegang hak atas tanah yang merupakan pemilik sebenarnya

Jika mengacu pada uraian diatas, nampak bahwa UUPA dan PP Nomor 24 Tahun 1997 tetap memperhatikan dua asas hukum yang penting yakni asas nemo plus yuris dan asas itikad baik guna memberikan perlindungan hukum kepada pemilik tanah. Asas nemo plus yuris dan asas itikad baik dapat dipakai sebagai dasar untuk memberikan perlindungan hukum kepada pemegang hak yang sebenarnya. Asas nemo plus yuris menyatakan bahwa orang tidak dapat mengalihkan hak melebihi hak yang ada padanya. Ini berarti bahwa pengalihan hak oleh orang yang tidak berhak adalah batal. Dengan demikian asas ini membertikan perlindungan hukum kepada pemegang hak yang sebenarnya. Asas itikad baik menyatakan bahwa orang yang memperoleh sesuatu hak dengan itikad baik, akan tetap menjadi pemegang hak yang sah menurut hukum. Dengan demikian nyata bahwa asas itikad baik bertujuan untuk melindungi orang yang beritikad baik.

Jika terjadi pembatalan sertifikat dengan dasar hak kepemilikan, menurut penulis sekalipun sertifikat sudah diterbitkan lebih dari 5 (lima) tahun, pemegang hak sebenarnya masih dimungkinkan untuk melakukan pembatalan sertifikat sepanjang dapat membuktikan bahwa perolehan hak keatas tanah oleh pemegang hak yang namanya tertera dalam sertifikat tidak memeperoleh hak tersebut dengan itikad baik. Oleh karena itu dapat tegas dikatakan bahwa UUPA maupun PP Nomor 24 TAahun 1997 telah memberikan jaminan perlindungan hukum dan kepastian hukum kepada pemegang hak yang sebenarnya yang secara itikad baik memperoleh hak atas tanah tersebut.

Dengan menggunakan lembaga Rechtsverwerking, seorang pemilik sebenarnya dapat mengajukan gugatan untuk mempertahankan haknya tersebut. Gugatan berdasarkan hak kepemilikan ini diajukan ke Pengadilan Negeri.

\section{Keputusan Tata Usaha Negara sebagai Dasar Pembatalan Sertifikat.}

Dimaksud dengan sub judul diatas ialah bahwa dengan adanya putusan penerbitan sertifikat oleh pihak yang berwenang (dhi Kantor Pertanahan), yang tidak sah secara hukum, dapat dipakai sebagai dasar pihak lain yang merasa memiliki hak atas tanah untuk mohon pembatalan sertifikat.

Sebagaimana telah diuraikan diatas, bahwa orang yang merasa memiliki hak atas tanah yang telah diterbitkan sertifikatnya, dapat mengajukan gugatan kepemilikan hak atas tanah hanya dalam rentangan waktu 5 (lima) tahun sejak diterbitkannya sertifikat. Namun dalam kenyatannya ada sertifikat yang telah diterbitkan 5 (lima) tahun atau lebih dinyatakan batal atau tidak sah oleh Pengadilan Tata Usaha Negara. Ada beberapa contoh putusan Pengadilan yang menyatakan batal atau tidak sah sertifikat yang telah dikeluarkan oleh pejabat yang berwenang dengan usia sertifikat lebih dari 5 (lima) tahun: 
1. Putusan Nomor 18/G/2014/PTUN. BJM

Perkara antara Eddi Zein (penggugat) melawan Kantor Pertanahan Kabupaten Tanah Laut dan DRA Damiana Maria, sebagai tergugat intervensi. Menjadi pokok gugatan adalah penerbitan sertifikat SHM No. 607 atas nama DRA Damiana Maria oleh Kantor Pertanahan Kabupaten Tanah Laut. Gugatan diajukan pada tahun 2014. Dengan demikian usia sertifikat HM atas nama DRA Damana lebih dari 5 (lima) tahun. Keputusan PTUN Banjarmasin menyatakan bahwa sertifikat SHM No. 607 atas nama DRA Damiana Maria adalah batal atau tidak sah, karena tidak sesuai dengan prosedur dan bertentangan dengan peraturan perundangan.

2. Putusan Nomor 34/G/2014/PTUN. SBY

Perkara antara PT Pilarmutiara sebagai penggugat melawan Kantor Pertanahan Surabaya I dan Drg Varina Santoso, sebagai tergugat intervensi. Pokok gugatannya adalah penerbitan sertifikat SHM No 91/Kelurahan Lontar pada tanggal 14 November 1995. Dengan demikian Nampak bahwa usia sertifikat SHM No 91/Kelurahan Lontar lebih dari 5 (lima) tahun. Keputusan PTUN Surabaya menyatakan batal sertifikat SHM No 91/Kelurahan Lontar.

3. Putusan Nomor 55/G/2001/PTUN. BDG

Perkara antara Tresna Hidayat sebagai penggugat melawan Kantor Pertanahan Kabupaten Tangerang, sebagai tergugat dan PT Lippo KawaraciTbk, sebagai tergugat intervensi. Pokok perkaranya adalah penerbitan sertifikat HGB No 6953/Bencongan atas nama PT Tunggal Reksa Kencana (sekarang PT Lippo Kawaraci Tbk).

Dari ketiga putusan tersebut yang ternyata semua sertifikat berusia lebih dari 5 (lima) tahun sejak diterbitkannya, dinyatakan batal atau tidak sah. Ini berarti bahwa sekalipun usia sertifikat telah lebih dari 5 ( lima) tahun, pemegang hak atas tanah yang namanya tercantum dalam sertfikat perlu "was2", bahwa pada suatu saat sertifikat hak atas tanahnya dapat dibatalkan. Jika dicermati gugatan tersebut, maka dasar gugatannya adalah Keputusan Tata Usaha Negara (selanjutnya disebut KPTUN). Dimaksud dengan Keputusan Tata Usaha Negara sebagaimana dalam Pasal 1 angka 3 Undang Undang Nomor 5 Tahun 1986 tentang Peradilan Tata Usaha Negara (selanjutnya disebut UU PTUN) menyatakan:

Keputusan Tata Usaha Negara adalah penetapan tertulis yang dikeluarkan oleh Badan atau Pejabat Tata Usaha Negara berdasarkan peraturan perundang-undangan yang berlaku bersifat konkret, individual, dan final, yang menimbulkan akibat hukum bagi sesorang atau badan hukum perdata.

Penerbitan sertifikat oleh Kepala Kantor Pendaftaran Tanah merupakan KTUN. Seorang yang merasa dirugikan dengan diterbitkannya sertifikat yang merupakan KTUN dapat mengajukan gugatan melalui Pengadilan Tata Usaha Negara (selanjutnya disebut PTUN), sebagaimana tersebut dalam Pasal 53 ayat (1) UU PTUN, dimana penggugat 
dapat menggugat KPTUN dapat dibatalkan atau dinyatakan tidak sah. ${ }^{13}$ Dengan mengacu pada Pasal 53 ayat (1) UU PTUN tersebut, adalah sah-sah saja jika para penggugat yang merasa dirugikan dengan terbitnya sertifikat yang dikeluarkan oleh Kantor Pertanahan yang merupakan KPTUN, mengajukan gugatan untuk mohon agar sertifikat dinyatakan batal atau tidak sah. Dalam gugatan ini tidak didasarkan pada hak kepemilikan akan tetapi didasarkan pada KPTUN yang14 :

a. Bertentangan dengan peraturan perundangan yang berlalu.

b. Dikeluarkan dengan menggunakan wewenang untuk tujuan lain dari maksud diberikannya wewenang tersebut.

c. Setelah mempertimbangkan semua kepentingan yang tersangkut dengan keputusan itu seharusnya tidak sampai pada pengambilan atau tidak pengambilan putusan tersebut.

Dalam melaksanakan pengujian terhadap KPTUN, hakim PTUN tidak terikat pada alasan yang diajukan oleh penggugat, dapat saja penggungat menggunakan alasan bertentangan dengan undang-undang, hakim mendasarkan pengujiannya pada penyalahgunaan wewenang. 15 Bahkan hakim dapat mendasarkan keputusannya pada Asas Asas Umum Pemerintahan Yang Baik (AAUPB), yang berada diluar ketentuan Pasal 53 ayat (2) UUPTUN, sekalipun tidak menjadi dasar dalam gugatan pemohon. ${ }^{16}$ Bahkan dikatakan oleh Suparto Wijoyo, alasan penggugat yang merupakan dasar pengujian keabsahan KPTUN bagi hakim, cukup dua saja secara alternative maupun komulatif, yakni ${ }^{17}$ :

1. KTUN tersebut bertentangan dengan peraturan perundangan

2. KTUN tersebut bertentangan dengan AUPB.

Dengan demikian adalah sah saja jika ada sertifikat yang telah berusia 5 (lima) tahun atau lebih dinyatakan batal atau tidak sah oleh hakim PTUN, karena dasar gugatannya adalah ketidak absahan KPTUN, sepanjang penggugat mendasarkan pada syarat tersebut diatas.

Dari uraian diatas, maka pembatalan sertifikat hak atas tanah yang merupakan salah satu cara yang dapat ditempuh untuk mempertahankan hak atas tanahnya, dapat dilakukan melalui dua cara yakni: pertama dengan gugatan perdata yang diajukan melalui Pengadilan Negeri yang mendasarkan pada hak kepemilikan atas tanah. Gugatan kepemilikan ini mendasarkan pada lembaga Rechtsverwerking yang diatur dalam Pasal 32 ayat (2) PP Nomor 24 Tahun 1997, dan kedua, gugatan atas KTUN yang diajukan melalui Pengadilan Tata Usaha Negara, dengan menggugat KTUN, yang mendasarkan pada Pasal 53 ayat (2) UU PTUN. Melalui asas Rechtsverwerking ini akan memberikan kepastian hukum kepada pihak yang

\footnotetext{
13 Lihat Pasal 53 UU PTUN.

14 Lihat Pasal 53 ayat (2) UU PTUN.

15 Suparto Wijoyo, Karakteristik Hukum Acara Peradilan Administrasi ( Airlangga University Press, 1997) 159.

16 Ibid.

17 Ibid.
} 
namanya telah tercantum dalam sertifikat dan telah memnuhi syarat sebagaimana tertuang dalam Pasal 32 ayat (2) PP Nomor 24 Tahun 1997. Dimaksudkan dengan itu adalah bahwa pihak yang namanya tercantum dalam sertifikat, akan aman atas kepemilikan tanahnya setelah 5 (lima) tahun. Sehingga akan menimbulkan kepastian hukum. Dengan dimungkinkannya gugatan tentang keabsahan sertifikat yang diterbitkan oleh Kantor Pertanahan, melalui gugatan tentang KTUN, akan mengakibatkan tujuan Pasal 32 ayat (2) PP Nomor 24 Tahun 1997 untuk memberikan kepastian hukum dan perlindungan hukum kepada pemegang hak yang namanya tersebut dalam sertifikat tidak akan tercapai. Kedua dasar pembatalan sertifikat tersebut sebenarnya memberikan perlindungan hukum kepada pihak yang dengan itikad baik memeproleh ha katas tanah. Tentu saja pembatalan sertifikat yang usianya lebih dari 5 (lima) tahun dengan mendasarkan pada KTUN, tidak mendukung terpenuhinya maksud Pasal 32 ayat (2) PP Nomor 24 Tahun 1997, berkaitan dengan kepastian hukum dan perlindungan hukum kepada pemegang hak yang tertera namanya dalam sertifikat, akan tetapi memberikan perlindungan hukum kepada pemegang hak sebenarnya.

Oleh karena itu, jika dua jalur upaya hukum yudisial tersebut dikaitkan dengan upaya memberikan kepastian hukum terkait dengan pendaftran tanah, maka pengadilan, apakah peradilan umum maupun peradilan TUN, harus berpegang pada lembaga Rechtsverwerking sebagaimana diatur dalam Pasal 32 ayat (2) PP Nomor 24 Tahun 1997. Itu artinya, pengadilan harus memberikan keuntungan kepada pemegang sertifikat hak atas tanah yang memenuhi syarat berdasarkan Pasal 32 ayat (2) PP Nomor 24 Tahun 1997 ketimbang penggungat, sehingga kepastian hukum sebagai ideal atau cita hukum dalam pendaftaran hak atas tanah dapat terwujud.

Ada pembedaan jenis putusan hakim yang berkaitan dengan pembatalan sertifikat yang diputuskan oleh hakim Pengadilan Umum dan hakim PTUN. Hakim Pengadilan Umum, dapat saja memutuskan dengan batal demi hukum (nietig) atau dapat dibatalkan (vernietigbaar). Putusan batal demi hukum (nietig), akan mengakibatkan bahwa sejak semula dianggap tidak terjadi hubungan hukum sebagaimana dipakai sebagai dasar kepemilikan hak atas tanah. Hal ini akan terjadi jika dalam gugatan terbukti bahwa perolehan tanah oleh pihak yang namanya tercantum dalam sertifikat, karena bertentangan dengan undang-undang, atau dapat dikatakan bahwa alas hak untuk memproleh hak atas tanah tersebut didasarkan pada causa yang tidak halal. ${ }^{18}$ Putusan hakim yang menyatakan dapat dibatalkan (vernietigbaar), akan berakibat bahwa hubungan hukum antara pemegang hak yang namanya tercantum dalam sertifikat akan dinyatakan tidak sah sebagai pemegang hak atas tanah, sejak putusan hakim dijatuhkan. Artinya bahwa perbuatan apapun yang dilakukan sebelum putusan diakui oleh hukum. Putusan hakim berlaku surut

18 Lihat Pasal 1320 yo Pasal 1337 KUH Perdata. 
terhadap perbutan yang dilakukan sebelumnya. Kondisi demikian akan terjadi jika alas hak yang mendasari kepemilkan tanah tersebut terjadi dengan tidak memenuhi Pasal 1320 KUH Perdata. ${ }^{19}$ Dengan demikian alas hak yang menjadi dasar kepemilkan hak atas tanah oleh pihak yang namanya tercantum dalam sertifikat menjadi sangat penting dalam pembatalan sertifikat karena kepemilikan. Perlu dipahami bahwa putusan Pengadilan berkaitan dengan kepemilikan sertifikat tidak secara otomatis akan membatalkan sertifikat yang telah diterbitkan. Ada langkah hukum yang perlu dilakukan yakni dengan mengajukan permohonan pembatalan sertifikat kepada pejabat yang menerbitkannya (dhi Kepala Kantor Pertanahan). Dalam putusan PTUN, hanya akan mengenal satu putusan saja yaitu putusan yang menyatakan perbuatan hukum pejabat yang berwenang dalam menerbitkan sertifikat melawan hukum atau tidah sah. Putusan hakim PTUN tidak akan berlaku surut.

\section{PENUTUP}

Berdasarkan apa yang telah dipaparkan diatas, dapat disimpulkan ada beberapa hal yang dapat dikemukakan dalam kesimpulan, yakni: pertama bahwa dengan adanya lembaga Rechtsverwerking akan memberikan kepastian hukum dan perlindungan hukum kepada pihak yang beritikad baik dalam memperoleh hak atas tanah, apakah pihak yang namanya tercantum dalam sertifikat maupun pemilik sebenarnya. Kedua; perlindungan hukum diberikan kepada pihak yang namanya tercantum dalam sertifikat, apabila yang bersangkutan memenuhi syarat yang tersebut dalam Pasal 32 ayat (2) PP Nomor 24 Tahun 1997, sedangkan untuk pemilik hak atas tanah yang benar, akan dilindungi hak kepemilikannya oleh asas itikad baik. Pembatalan sertifikat karena melanggar itikad baik dalam kepemilikannya akan dapat dilakukan kapapun juga. Keempat; Ada perbedaan sebagai dasar gugatan pembatalan sertifikat melalui Pengadilan Negeri dengan menggunakan lembaga Rechtsverwerking dan asas itikad baik dengan gugatan melalui PTUN. Dasar gugatan Rechtsverwerking dan itikad baik adalah berkaitan dengan kepemilikan hak atas tanah, sehingga hak keperdataan yang menjadi dasarnya, sedangkan gugatan melalui PTUN dasar gugatannya adalah KTUN, yakni penerbitan sertifikat oleh Kantor Pertanahan yang cacat secara prosedural, sehingga tidak sah karena bertentangan dengan peraturan yang berlaku.

\section{DAFTAR BACAAN}

\section{Buku}

Budhayati, Tri, Christiana, Hak Atas Tanah, Peralihan Dan Pendaftaran (FH - UKSW 2017).

Budi Harsono, Hukum Agraria Indonesia: Sejarah Pembentukan Undang Undang Pokok Agraria, Isi 
Dan Pelaksanannya (Jambatan 1999).

Mulyadi Kartini dan Widjaja Gunawan, Hak Hak Atas Tanah (Predand Medika 2004).

Sutedi Andrian, Peralihan Hak Atas Tanah Dan Pendaftaranya (Sinar Grafika 2007.

Wijoyo, Suparto, Karakteristik Hukum Acara Peradilan Administrasi. (Airlangga University Press 1997).

Wahid Muhtar, Memaknai Kepastian Hukum Hak Milik Atas Tanah; Suatau Analisis Dengan Pendekatan Terpadu Secara Normatif Dan Sosiologis (Republika 2008).

\section{Peraturan Perundang-undangan}

Kitab Undang Undang Hukum Perdata.

Undang-Undang Republik Indonesia Nomor 5 Tahun 1960 tentang Peraturan Dasar Pokok Pokok Agraria.

Undang-Undang Republik Indonesia Nomor 5 Tahun 1986 tentang Peradilan Tata Usaha Negara.

Peraturan Pemerintah Nomor 24 Tahun 1997 tentang Pendaftaran Tanah. 